\title{
PUBLIC REAL ESTATE MANAGEMENT SYSTEM IN THE PROCEDURAL APPROACH - A CASE STUDY OF POLAND AND SLOVAKIA
}

\author{
Marta Gross, PhD \\ Faculty of Geodesy and Land Management \\ University of Warmia and Mazury in Olsztyn \\ e-mail:marta.gross@uwm.edu.pl \\ Ryszard Źróbek, prof., PhD \\ Faculty of Geodesy and Land Management \\ University of Warmia and Mazury in Olsztyn \\ e-mail: rzrobek@uwm.edu.pl \\ Daniela Špirková, Assoc. Prof. Ing. \\ Institute of Management \\ Slovak University of Technology in Bratislava \\ e-mail:daniela.spirkova@stuba.sk
}

\begin{abstract}
Public real estate management is performed according to country-specific procedures. However, there are some features which are common for all post-socialist countries. It may be possible to implement and transfer into the Polish system the good management practice which has been developed by leading countries. On the other hand, Poles may have a chance to become acquainted with the rules governing public real estate management in other countries and to identify some practices which ought to be avoided. There is no need to implement faithfully those procedures which in other countries have been recognized as generally inadequate or inefficient and have been replaced by new solutions. This pertains to some principal components of the real estate management system.

The aim of the paper has been to present public real estate management systems in Poland and Slovakia in the context of good governance, and to suggest some indicators for assessing the procedures in these systems in terms of their efficiency.
\end{abstract}

Key words: public real estate, management, good governance.

JEL Classification: H70.

Citation: Cellmer R., 2014, The possibilities and limitations of geostatistical methods in real estate market analyses, Real Estate Management and Valuation, vol. 22, no. 3, s. 63-72.

DOI: $10.2478 /$ remav-2014-0028

\section{Introduction}

The subject of public real estate management remains a valid research issue despite public real estate becoming rarer, especially in developed countries. This fact hasn't stopped the publishing of more and more papers concerning public real estate management and its efficiency, or the efficiency of the real estate market in general (GODFREY 2007; NOWACKI 2008; KAGANOVA et al. 2008; KOKOT, GNAT 2010; STRUZIK, ŹRÓBEK 2010; YUNUS et al. 2010; CONSTANTIN et al. 2012; MARONA 2012; DAWIDOWICZ et al. 2013; GROSS, ŹRÓBEK 2013). 
Public real estate management is performed according to country-specific procedures. However, there are some features which are common to all post-socialist countries. It is possible to implement and transfer into the Polish system some elements of good management practice developed by leading countries. On the other hand, Poles can become acquainted with rules governing real estate management in other countries and identify practices which may be avoided. There is no need to implement faithfully those procedures which in other countries have been recognized as generally inadequate or inefficient, and have been replaced by new solutions. This pertains to principal components of the real estate management system.

The paper presents selected real estate management procedures in Poland and Slovakia. Of the two, Poland is a much larger country, in which the local government system is divided into three main tiers: 16 voivodeships (provinces), 314 poviats (districts) (as well as 66 cities with the poviat status) and 2,479 gminas (communes) (GUS 2014). Slovakia is divided into 8 regions (higher territorial units) and 79 districts. There are 2,922 municipalities, including the cities of Bratislava and Košice, each with its own coat of arms (STATISTICAL OFFICE OF THE SLOVAK REPUBLIC 2014). The term public real estate is defined by law in Poland but not in Slovakia. According to the Polish REAL ESTATE MANAGEMENT ACT (1997), it is real estate which is owned by the State Treasury, community, poviat or voivodeship, is not let into perpetual usufruct, and is a subject of perpetual usufruct by the State Treasury, community, poviat or voivodeship.

Public real estate management in Poland, as well as in Slovakia, is regulated by several legal acts. In Poland these are the Constitution, Civil Code and other acts (the most important being the REAL ESTATE MANAGEMENT ACT (1997) and executive ordinances). The most important legal acts of Slovakia are the Civil Code, the LAW ON ADMINISTRATION OF THE PROPERTY OF PUBLIC INSTITUTIONS (2004), the LAW ABOUT THE ADMINISTRATION OF STATE PROPERTY (1993) and the Cadastral Act.

The aim of the paper is to present the public real estate management systems in Poland and Slovakia in the context of good governance, and to point to some indicators that are useful in assessing selected procedures in these systems in terms of their efficiency.

\section{Principles of good governance as a tool for effective management}

Good governance "leads to better decisions, helps local government meet its legislative responsibilities and most importantly provides an ethical basis for governance" (GOOD GOVERNANCE GUIDE 2014). It enables a comprehensive assessment of the real estate management system in a given country, and helps to identify its weaknesses, e.g. defective operation of the system's components. Moreover, good governance facilitates:

- the determination of an appropriate real estate management policy;

- an integrated approach to real estate management which will help to achieve sustainable development.

According to the COMMISSION OF THE EUROPEAN COMMUNITIES (2001); MRR, DKPS (2008) and GROSS (2012), there are five basic principles of good governance:

1) Openness - a real estate service should be open to the third party's questions and ought to answer them in a simple way;

2) Participation - society should be able to participate in real estate management procedures, for example people should have an impact on the related decision-making processes;

3) Accountability - local government units and other public institutions responsible for real estate management should know what they are held accountable for (a real estate management system should be decentralized because this ensures flexibility and reduces time needed to make decisions, though this sometimes raises costs);

4) Effectiveness - management aims should be determined in a simple way, including their future and past impact on the management policy; this principle should encompass the following aspects: subsidiarity, economy and optimality;

5) Coherence - politics and activities concerning public real estate management should be understandable.

"Each principle is important by itself. But they cannot be achieved through separate actions" (COMMISSION OF THE EUROPEAN COMMUNITIES 2001, p. 10). They should be realized in a complex way in order to make real estate management efficient, because no single principle is more or less significant. 
Good governance principles have an impact on real estate management (Fig. 1). Public entities as well as private ones are involved in management processes. Relations which are based on the decision-making process and consultations exist between the two. Good governance principles lead to sustainable real estate management. "Governance refers to the manner in which power is exercised by governments in managing a country's social, economic, and spatial resources. It simply means the processes of decision making and the processes by which decisions are implemented," (WILLIAMSON et al. 2009, p. 31). In order to attain sustainable real estate management, it is crucial to use real estate information systems that are up to date and precise. Generally speaking, "Land management requires interdisciplinary skills based on the technical, natural, and social sciences," (WILLIAMSON et al. 2009, p. 117).

Good governance principles

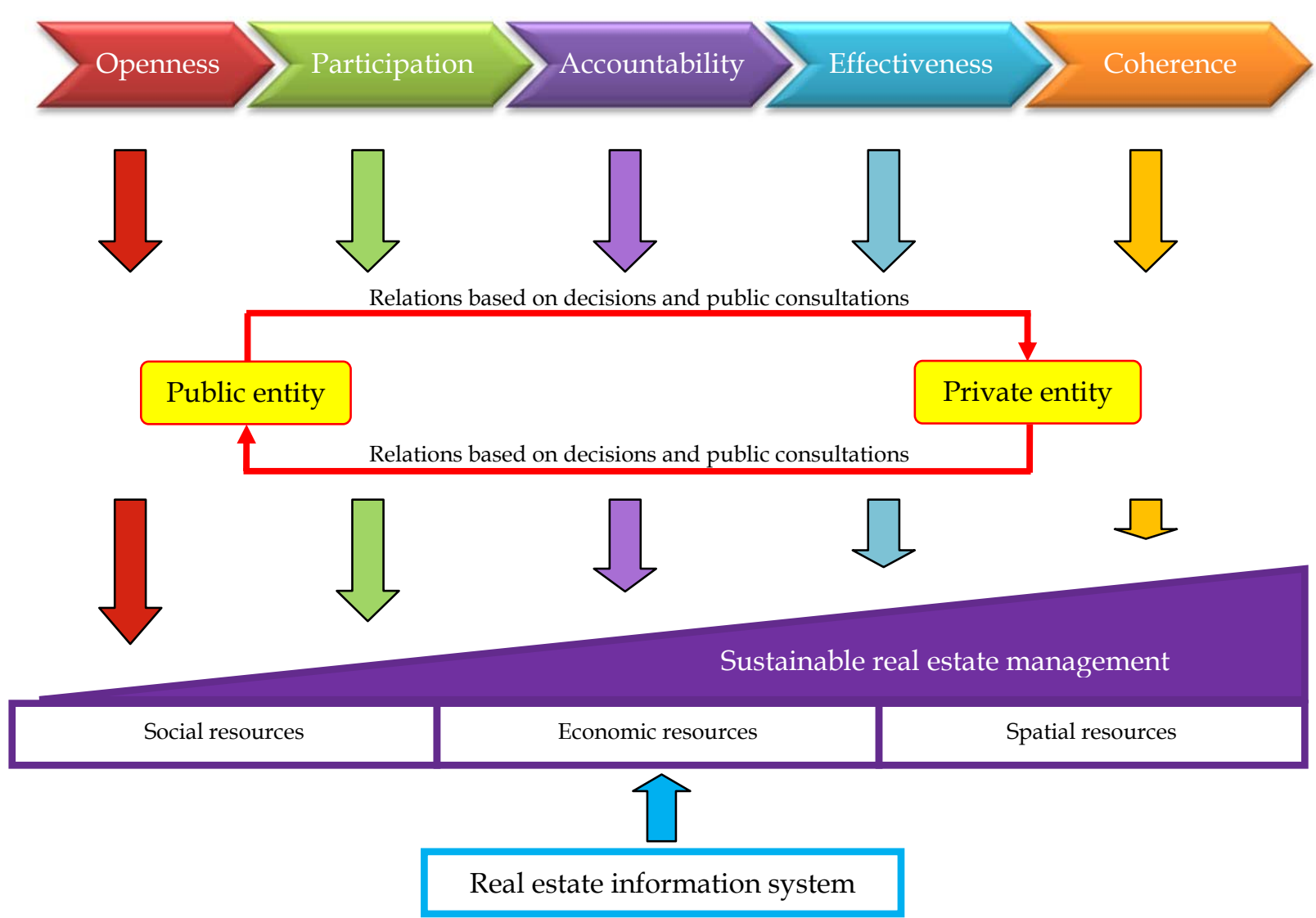

Fig. 1. Good governance principles and their impact on real estate management. Source: own elaboration based on MRR, DKPS (2008) and WILLIAMSON et al. (2009)

\section{Chosen procedures in real estate management in Poland and Slovakia}

The paper compares three procedures of real estate management in Poland and in Slovakia, i.e. selling public real estate, the registration of rights and public private partnership.

In Slovakia, a state property can be sold when it is currently disused and will not be used by the state in the future, provided the following two conditions are satisfied:

- first, a given real estate property should be offered for sale to state contributory organizations which operate in the area where the property is situated, and then to other contributory organizations (most importantly, these organizations must decide how to use this property; it is unacceptable for a given real estate to be purchased and not used); these organizations have 30 days to determine whether they want to buy a state property or not (LAW ABOUT THE ADMINISTRATION OF STATE PROPERTY 1993);

- if the contributory organizations are not interested in buying a certain state real estate, the state is obliged to sell it to the municipality or one of the eight higher territorial units - regions (LAW 
ABOUT THE ADMINISTRATION OF STATE PROPERTY 1993 or LAW ABOUT TRANSFER OF PROPERTY INTO THE OWNERSHIP OF SLOVAK REPUBLIC 2004).

THE LAW ON ADMINISTRATION OF THE PROPERTY OF PUBLIC INSTITUTIONS (2004) refers to the administration of properties owned by a public institution which for the purposes of this law is a legal entity, as well as by a public institution which also owns real estate. A public institution can sell a disused immovable property by public tender to the highest bidder. This highest bid cannot be lower than an adequate price, i.e. the lowest possible price. The term disused immovable property is defined by law as real estate which no longer serves and in the future will not serve a given public institution to perform its basic and other tasks. The statutory body of a public service institution decides whether or not a given real estate it owns is useful. Any public service institution is authorized to temporarily hire out or lend a useless property.

According to the LAW ABOUT THE ADMINISTRATION OF STATE PROPERTY (1993), the Ministry of Finance of the Slovak Republic can decide to withdraw a state immovable property and at the same time appoint a new trustee. Such a withdrawal decision regarding the state's real estate administration and appointment of a new administrator must contain precise specifications of:

- the state's real property whose administration is going to be withdrawn;

- the current administrator of the state real property;

- the new administrator;

- the justification of the withdrawal decision.

An administrator of an immovable state property is obliged to ensure its registration in a real estate register. Sometimes, a public entity may not disclose the fact that a real estate property will be sold or such information may be published with a delay. This might prohibit potential buyers from participating in a tender.

Public properties in Poland are also sold in a tender bid (oral or written, limited or unlimited). According to the REAL EsTATE MANAGEMENT ACT (1997), the price for a real estate cannot be lower than:

- its market value in the first tender;

- $50 \%$ of the market value in the second tender, when the first tender ended without choosing the winner;

- $40 \%$ of the market value, negotiable when the second tender ended without choosing the winner.

There are also some cases when public real estate can be sold without a public tender, for example when (REAL ESTATE MANAGEMENT ACT 1997):

- real estate is sold in favor of a person possessing the priority right in its acquisition;

- the purchase contract is done between state and local government units, or between two local government units;

- the acquisition is done by the way of exchange or donation;

- the property is sold to its perpetual usufructuary.

According to one of the good governance principles, i.e. effectiveness, selling public real estate in Poland raises one serious problem - the acquisition of such an immovable property at a lower price. Sometimes, potential buyers postpone their decision hoping to buy a given property at the lowest possible price. They refrain from bidding during the first two tenders, hoping to acquire a given property by negotiation (especially when there is little interest in buying this real estate). Moreover, in both countries, plans of the public real estate resources are created, which is highly advantageous, especially when planning which properties should be sold.

Both Poland and Slovakia have a cadastre. In Slovakia, real estate registration in the cadastre system held by the Land Registry Office began in 1993. Real estate rights, such as ownership, mortgage and pre-emption rights are registered in the cadastre. The cadastre also serves as a database, in particular to protect rights of real estate, for tax and fee purposes, to valuate real estate, to protect agricultural and forest lands, and to provide information for the construction and development of information systems. An online Cadastral Portal was created in 2002. It enables logged and unlogged users to obtain basic information about registered real estate via the Internet. The Cadastral Portal webpage enables logged users to (CADASTRAL PORTAL 2014):

- search through registered identifiers;

- search data via a graphic interface; 
- search for information on cadastral procedures or proceedings.

If users are registered and have their own logins, they can (CADASTRAL PORTAL 2014):

- generate PDF outputs referring to the user's selection;

- search information on cadastral procedures according to a time period;

- generate statistics on cadastral districts.

The Office of Geodesy, Cartography and Cadastre of the Slovak Republic is the central state organ in the cadastre. Other government organs belong to the cadastre administration. They are controlled by the Land Registry Office, whose duty is:

- to develop concepts and directions for the development of the cadastre;

- to administer the cadastre in each district;

- to perform cadastral inspections; and

- to ensure international cooperation in the field of the cadastre.

The Real Estate Cadastre of the Slovak Republic currently ensures access to information through an electronic system, but the data are insufficient for creating maps of prices. It also affects the development of the institutional environment in the area of the Slovak Republic.

There are two registers in Poland - a land and mortgage register (ksiega wieczysta) and a land register (ewidencja gruntów $i$ budynków). The former one is maintained by district courts, with information divided into four sections: real estate, its owner or perpetual usufructuary, burdens and mortgages. It is possible to access this register online as more and more individual records concerning real estate are available in the electronic version. The land register is a more technical register with spatial information about real estate, such as its area, borders, use of land, buildings and premises, land class, etc. It is maintained by a prefect (the chairman of a poviat board) or the mayor of a city with a poviat status. Poland has a 2D cadastre, but works are in progress to convert it to a 3D one.

The concept of public private partnership (PPP) functions in Poland and in Slovakia. The most important difference between the countries is the frequency of its use. Compared to its neighbors like Poland, the Czech Republic or Hungary, Slovakia seems to be slightly lagging behind with the use of PPP. The legal basis under which PPP projects are realized is laid out in the LAW ABOUT PUBLIC PROCUREMENT (2006). According to THE ECONOMIST INTELLIGENCE UNIT $(2013$, p. 69) there are no legal barriers "for the execution of PPP projects at the local or regional level."

Currently PPP projects in Slovakia are developed mainly in the transport sector. The only ongoing PPP project is the construction of the R1 expressway between the towns NITRA - BELADCE TEKOVSKÉ NEMCE and the northern bypass of BANSKÁ BYSTRICA (52 km in total).

In Poland, PPP projects are mainly regulated by the PUBLIC PRIVATE PARTNERSHIP ACT (2008), which states that a private entity is obliged to implement a project and bear the whole or part of the expenditure it will incur. A private party in the project receives remuneration for the project's execution. On the other hand, a public entity is obliged to cooperate with a private partner to achieve the purpose of a given project, especially by contributing its own share. Currently there are 70 PPP projects going on in Poland (Fig. 2), mostly in the south and in the centre of the country.

Table 1 presents the advantages and disadvantages of PPP projects in the analyzed countries. The situation in Poland is slightly better. Not only is there a clear division of risk, but tasks and responsibilities related to these tasks are clearly specified. Moreover, the state policy is in favor of PPP projects, mainly because of the urgent need for public infrastructure investment.

\section{Methodology and the results of the comparison}

The authors took into consideration three procedures involved in public real estate management in Poland and Slovakia, which have been described in the third section of this paper according to the case study method.

The research additionally included some indicators to assess the three procedures of these systems in terms of their efficiency. A method based on a 0-1 scale was used to compare the Polish and Slovakian procedures. A value of 0 signifies the absence of the analyzed feature or a worse index for a given country. A 1 means that the analyzed feature exists, or that the analyzed index is better than in the other country. Six indicators in each procedure were chosen. They are either mentioned in part three of this article or have been found in international studies. The applied method was chosen because there were only two countries to compare. Moreover, this method can demonstrate which 
country is better in the performance of each procedure. Table 2 shows the assessment of the analyzed management procedures. It is followed by an explanation of the index ranks.

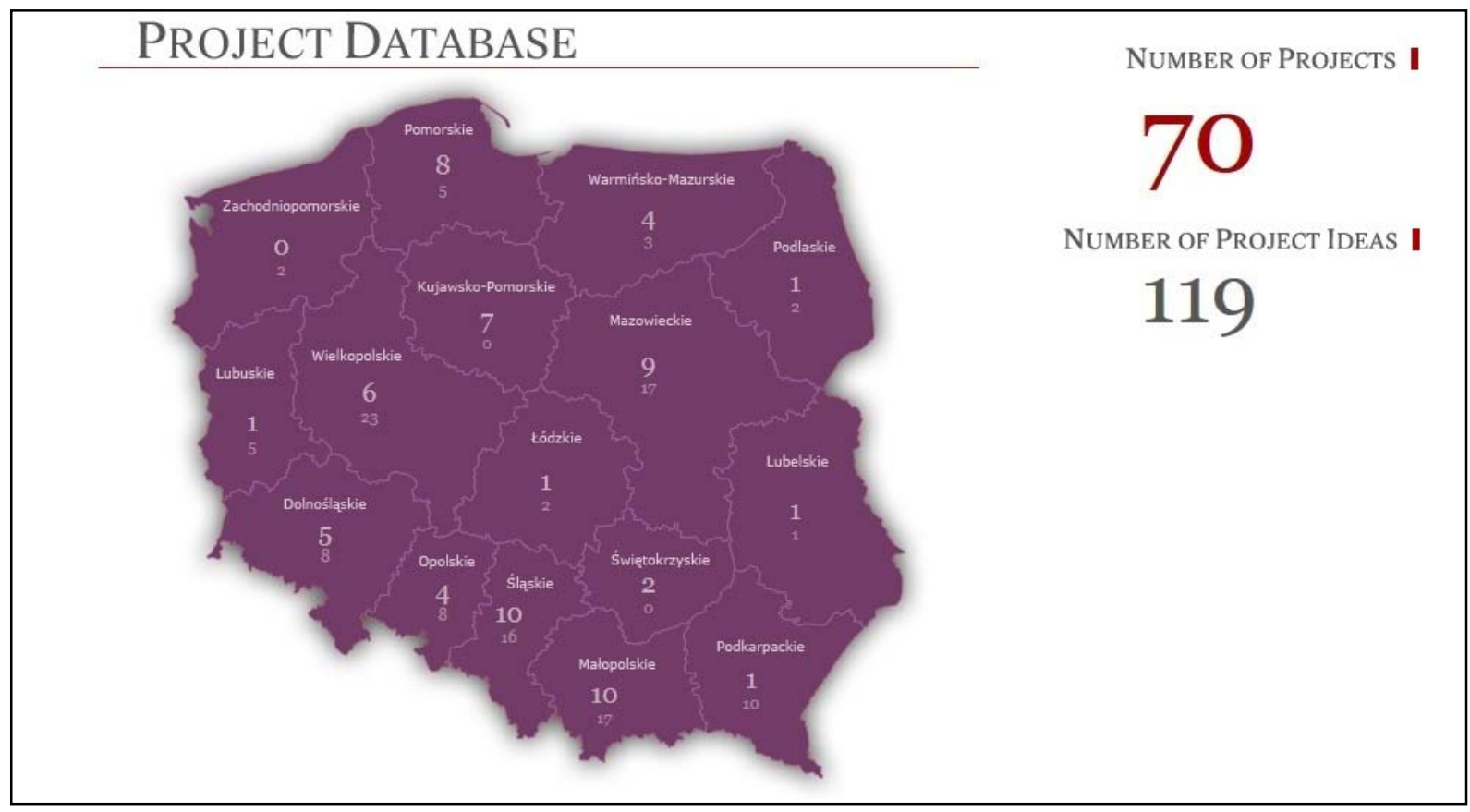

Fig. 2. Number of PPP projects in Poland, in individual voivodeships (provinces). Source: PublicPRIVATE PARTNERShIPS PROJECT DATABASE (2014).

Table 1

Advantages and disadvantages of PPPs in Poland and Slovakia

\begin{tabular}{|c|c|c|}
\hline Specification & Poland & Slovakia \\
\hline Advantages & $\begin{array}{l}\text { - firm regulations in the scope of PPPs; } \\
\text { - political will to use PPPs, especially } \\
\text { in public infrastructure; } \\
\text { - well-regulated capital market; } \\
\text { - division of tasks, risk and } \\
\text { responsibilities; } \\
\text { - benefits for private partner and } \\
\text { public task realization for public } \\
\text { entity. }\end{array}$ & $\begin{array}{l}\text { - rules aligned with the EU legislation; } \\
\text { - firmness, transparency and fair } \\
\text { regulations concerning project } \\
\text { selection; } \\
\text { - identification of risk. }\end{array}$ \\
\hline Disadvantages & $\begin{array}{l}\text { - lack of guidelines how to select } \\
\text { the form of PPP; } \\
\text { - lack of a national agency responsible } \\
\text { for PPP development; } \\
\text { - lack of appropriate knowledge about } \\
\text { PPPs. }\end{array}$ & $\begin{array}{l}\text { - duration of the bidding process; } \\
\text { - lack of political support for PPP } \\
\text { projects; } \\
\text { - delays / cancellations of PPP projects; } \\
\text { - lack of state funds and financial } \\
\text { liquidity. }\end{array}$ \\
\hline
\end{tabular}

Source: own elaboration, based on WAWRZYNIAK (2012) and THE ECONOMIST INTELLIGENCE UNIT (2013).

The first procedure to be analyzed was the sale of public real estate. Both countries have been creating plans of public real estate resource use (one point for each). The accessibility of information about public properties for sale is better in Poland (one point). Slovakian public entities sometimes do not release information about the selling of real estate. The next indicator was the sale price. Both countries were granted one point because they both set the lowest possible price at which the public real estate can be sold. Moreover, three indices testing potential corruption were included. The first one, namely the control of corruption, is one of the Worldwide Governance Indicators created by KAUfMANN et al. (2010). Poland scored 0.6 (one point) and Slovakia was given 0.1 (zero points). The last two indicators were created by TRANSPARENCY INTERNATIONAL (2013). Poland earned 60 points 
and was ranked $38^{\text {th }}$ out of a total of 177 analyzed countries, whereas Slovakia was granted 47 points and $61^{\text {st }}$ place. In short, Poland earned 1 point twice and Slovakia was given zero points on all occasions.

Table 2

Poland and Slovakia - assessment of chosen management procedures

\begin{tabular}{|c|c|c|}
\hline & Poland & Slovakia \\
\hline \multicolumn{3}{|l|}{ Sale of public real estate } \\
\hline $\begin{array}{l}\text { plans regarding the use of public real restate } \\
\text { resources }\end{array}$ & 1 & 1 \\
\hline availability of sale information & 1 & 0 \\
\hline sale price & 1 & 1 \\
\hline control of corruption & 1 & 0 \\
\hline corruption perceptions index (score) & 1 & 0 \\
\hline \multirow{2}{*}{ corruption perceptions index (rank) } & 1 & 0 \\
\hline & 6 & 2 \\
\hline \multicolumn{3}{|l|}{ Registration of rights } \\
\hline existing cadastre & 1 & 1 \\
\hline real estate rights registration available on-line & 0 & 1 \\
\hline existing integrated information system & 0 & 1 \\
\hline registering property & 0 & 1 \\
\hline procedures & 0 & 1 \\
\hline \multirow[t]{2}{*}{ time } & 1 & 0 \\
\hline & 2 & 5 \\
\hline \multicolumn{3}{|l|}{ PPPs } \\
\hline evaluating PPPs & 1 & 0 \\
\hline number of projects & 1 & 0 \\
\hline dominance of advantages & 1 & 0 \\
\hline government effectiveness & 0 & 1 \\
\hline voice and accountability & 1 & 0 \\
\hline rule of law & 1 & 0 \\
\hline Score & 5 & 1 \\
\hline Total score & 13 & 8 \\
\hline
\end{tabular}

Source: own elaboration, based on KAUFMANN et al. (2010), THE ECONOMIST INTELLIGENCE UNIT (2013), TRANSPARENCY INTERNATIONAL (2013), THE WORLD BANK \& THE INTERNATIONAL FINANCE CORPORATION (2014).

The second procedure which we looked at was the registration of real estate rights. Both Poland and Slovakia maintain a cadastre (one point for each country). In Slovakia, it is possible to register real estate online (one point). Moreover, this country has an integrated information system (one point). The last three indicators were created by THE WORLD BANK \& THE INTERNATIONAL FINANCE CORPORATION (2014). First, there was an indicator which assessed the registering of properties. Poland was ranked $22^{\text {nd }}$ (zero points), while Slovakia took $11^{\text {th }}$ place (one point). The second index was the number of procedures required to register real estate. There were 3 procedures in Slovakia (one point) and 4 in Poland (zero points). The last indicator was the time it took to register real estate: 16.5 days in Slovakia (zero points) and 6.5 days in Poland (one point).

The last of the analyzed procedures were the PPPs. The first indicator was created by THE ECONOMIST INTELLIGENCE UNIT (2013). Poland was recognized as an emerging country with a score of 52.0 (one point), while Slovakia was also recognized as an emerging country but scored 47.6 (zero 
points). The most important difference between the analyzed countries is the number of ongoing PPP projects: 70 in Poland (one point) and only one in Slovakia (zero points). Table 1 presents the advantages and disadvantages of PPPs in both countries. In Poland, advantages prevailed, which is why this country received one point. The last three indicators were created by KAUFMANN et al. (2010), and are part of the Worldwide Governance Indicators. The first of these indicators is the government's effectiveness. Poland scored 0.7 (zero points) and Slovakia - 0.8 (one point). The next index was voice and accountability, for which Poland was given a score of 1.1 (one point) and Slovakia received a score of 1.0 (zero points). The last indicator was the rule of law, with Poland earning 0.7 (one point) and Slovakia - 0.5 (zero points).

The final results of the comparison are illustrated in Figure 3. Poland earned a total of 13 points, with Slovakia receiving 8 (Table 2). Overall, the analyzed countries are similar, but certain details are different. The Polish system is better at two procedures - the sale of public real estate and PPPs. Information about public tenders in Poland is published. Moreover, corruption seems to be under stricter control in this country. The execution of PPPs is better, which is manifested by a higher number of such projects and, what is strictly connected to it, more transparent legal regulations concerning PPPs in Poland. There is also a clear division of tasks, risk and responsibilities between public entities and private partners. Poland needs public private partnerships, especially for developing infrastructure, which is why politicians make more frequent attempts at encouraging PPPs and promoting their effective use. This is the reason why PPPs were evaluated higher than in the Slovak Republic.

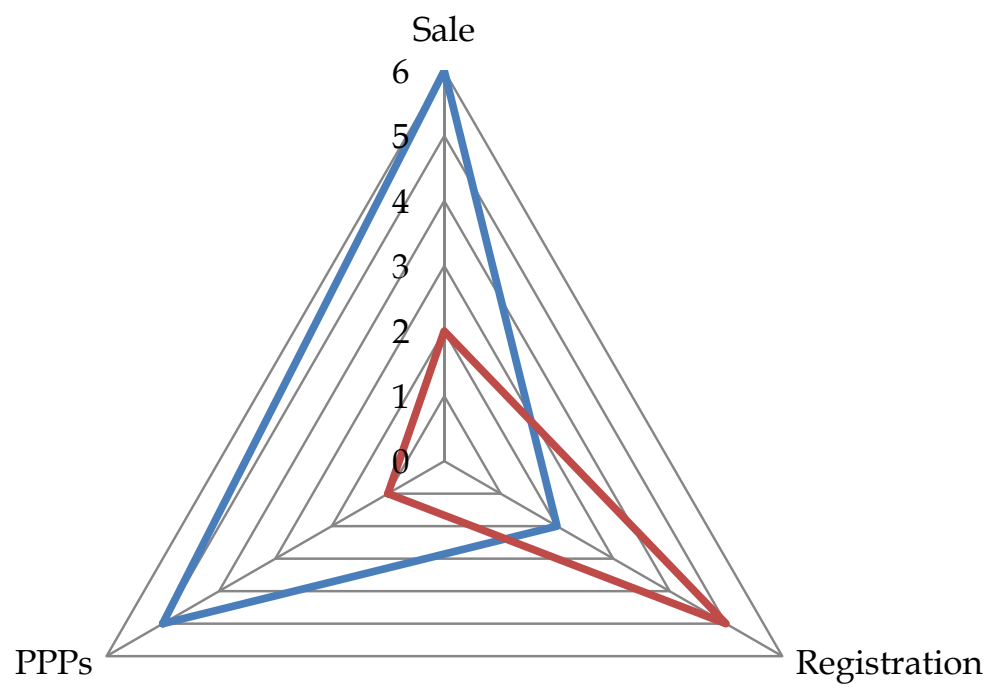

Poland

Slovakia

Fig. 3. Poland and Slovakia - results of comparison. Source: own elaboration.

On the other hand, Poland is inferior to Slovakia in real estate registration. Works on the creation of an integrated information system have not been completed yet. In Slovakia, it is possible to register real estate online. There is one procedure fewer than in Poland to register a property. The only thing which Slovakia should improve in this scope is the time needed to register real estate, because nowadays it lasts 10 days more than in Poland.

\section{Conclusions}

This paper confirms that it is possible to use one of the good governance principles, i.e. effectiveness, for the assessment of public real estate management systems. This principle is applicable not only to 
such issues as real estate registration, the sales of public real estate or PPPs, but also to others. It is also possible to choose some indicators that can show how the principle of effectiveness is performed in chosen procedures in different countries.

The research reported in this paper shows that Poland is better in selling public real estate and performing PPP projects. On the other hand, Slovakia fared better in real estate registration. Both countries should make some improvements in the scope of these three procedures. They should adhere to good management practice which has been developed by leading countries, while avoiding some procedures which have proved inadequate or inefficient. One must keep in mind however that the system of public estate management, for example in the UK, "has evolved over a long period of time. Transition economies have had to create fully-fledged systems soon after their property markets became legal. Market economies have had centuries to evolve rules of how markets ought to behave" (WALACIK et al. 2013, p. 85).

\section{References}

CONSTANTIN D.L., Dragusin M., Petrescu R.M., IOSIF A.E. 2012. The effective management of municipal real property. The question of services for the business use of real property. AMFITEATRU ECONOMIC, 2012, Vol. 14, Issue Special No. 6, Pages 738-754

COMMISSION OF THE EUROPEAN COMMUNITIES. 2001. EUROPEAN GOVERNANCE. A WHITE PAPER. http://eur-lex.europa.eu/LexUriServ/site/en/com/2001/com2001_0428en01.pdf. October 2011

DAWIDOWICZ A., RADZEWICZ A., RENIGIER-BIEOZOR M. 2013. Algorithm for purposes of determining real estate markets efficiency with help of land administration system. Survey Review, DOI: 10.1179/1752270613Y.0000000080

GODFREY E.B. 2007. Public land management: Lessons from the past and implications for the future. JOURNAL OF AGRICULTURAL AND RESOURCE ECONOMICS, Volume 32, Issue 3. Pages: 567567

GROsS M. 2012. Analiza wybranych procedur gospodarowania nieruchomościami publicznymi wujęciu międzynarodowym (Analysis of chosen real estate management procedures in the international aspect). Studia i Materiały Towarzystwa Naukowego Nieruchomości, Vol. 20, No 4. Olsztyn. Pages 169-178

Gross M., ŹRÓBEK R., 2013, Public real estate management in post-socialist countries, Real Estate Management and Valuation. Volume 21, Issue 4, Pages 11-16, ISSN (Online) 1733-2478, DOI: 10.2478/remav-2013-0032, January 2014

KAGANOVA O., AKMATOV A., UNDElAND C. 2008. Introducing more transparent and efficient land management in post-socialist cities: lessons from Kyrgyzstan, International Journal of Strategic Property Management. 01/2008; 12(3), Pages 161-181, DOI:10.3846/1648-715X.2008.12.161-181

KAUfMANN D., AART K. AND MASSIMO M. 2010. The Worldwide Governance Indicators: Methodology and Analytical Issues. World Bank Policy Research Working Paper No. 5430. papers.ssrn.com/sol3/papers.cfm?abstract_id=1682130 . February 2014

КОкOT S., GNAT S. 2010. Problem efektywności gospodarki nieruchomościami gmin. (The problem of the efficiency of the economy of communes' properties) Studia i Materiały Towarzystwa Naukowego Nieruchomości. Vol. 18, Nr 2. Pages 29-44

MARONA B. 2012. Ocena racjonalności gospodarowania a cele posiadania nieruchomości w sektorze prywatnym i publicznym (Rational real estate management in the context of ownership goals in private and public sector). Proceedings from V Konferencja Naukowa „Efektywność źródłem bogactwa narodów” 2325 January 2012. http://efektywnosc.konferencja.org/ufiles/File/Marona_Bartlomiej.pdf. June 2012

MRR, DKPS. Ministerstwo RozWOJU RegIONALNEGO, DEPARTAMENT KOORDYNACJI POLITYKI StRUKTURALNEJ. 2008. KONCEPCJA GOOD GOVERNANCE - REFLEKSJE DO DYSKUSJI. http://www.mrr.gov.pl/aktualnosci/fundusze_europejskie_2007_2013/Documents/koncepcja_g ood_governance.pdf. October 2011

NOWACKI P. 2008. Efektywne gospodarowanie nieruchomościami worganizacjach gospodarczych $z$ wykorzystaniem praktyk facility management (Efficient real estate management in commercial entities with the aid of facility management practices). Studia i Materiały Towarzystwa Naukowego Nieruchomości, Vol. 16, Nr 1. Olsztyn. Pages 53-66

STRUZIK A., ŹRÓBEK R. 2010. Efektywność w gospodarowaniu publicznymi zasobami nieruchomości: metody oceny optacalności publicznych projektów inwestycyjnych (Effectiveness of management of public resources 
of real estates: methods of evaluation cost effectiveness of public investment projects). Przegląd Geodezyjny Nr 2. Pages 7-14

THE ECONOMIST INTELLIGENCE UNIT. 2013. Evaluating the environment for public-private partnerships in Eastern Europe and the Commonwealth of Independent States. The 2012 EECIS Infrascope. Findings and methodology. Commissioned by the European Bank for Reconstruction and Development. www.ebrd.com/downloads/news/eecis.pdf. January 2014

THE World Bank \& THE International FinAnCE Corporation. 2014. Doing Business 2014. Understanding Regulations for Small and Medium-Size Enterprises. Washington: International Bank for Reconstruction and Development / The World Bank

TRANSPARENCY INTERNATIONAL. 2013. CORRUPTION PERCEPTIONS INDEX 2013. Berlin: Transparency International. www.transparency.org. February 2014

WalaciK M., Grover R., Adamuscin A., 2013, Valuation systems in Poland, Slovakia and United Kingdom- comparative study, Real Estate Management and Valuation. Volume 21, Issue 4, Pages 7586, ISSN (Online) 1733-2478, DOI: 10.2478/remav-2013-0039, January 2014

WAWRZYNIAK M. 2012. The legal framework for PPPs in Poland. PPP Magazine. Autumn 2012. Pages 1522. ippp.pl/wp-content/uploads/2012/09/PPPm_inside_Autumn_2012_final_with_cover_lowres. pdf. January 2014

Williamson I., Enemark S., Wallace J., Rajabifard A. 2009. Land Administration for Sustainable Development. ESRI Press Academic. Redlands, California

Yunus N., HANSZ J.A., KenNedy P.J. 2010. Dynamic Interactions Between Private and Public Real Estate Markets: Some International Evidence. JOURNAL OF REAL ESTATE FINANCE AND ECONOMICS, Volume 45, Issue 4. Pages: 1021-1040. DOI: 10.1007/s11146-010-9297-5

LAW ON ADMINISTRATION OF THE PROPERTY OF PUBLIC INSTITUTIONS NO. 176/2004 Coll., Republic of Slovakia

LAW ABOUT PUBLIC PROCUREMENT no. 25/2006 Coll., Republic of Slovakia

LAW ABOUT THE ADMINISTRATION OF STATE PROPERTY no. 278/1993 Coll., Republic of Slovakia

LAW ABOUT TRANSFER OF PROPERTY INTO THE OWNERSHIP OF SLOVAK REPUBLIC no. 172/2004 Coll., Republic of Slovakia

PubliC PRIVATE PARTNERSHIP ACT. 19th December 2008. Published in Dz. U. No 19, item 100 from 2009 with later changes, Republic of Poland

Real estate management ACt. 21 ${ }^{\text {st }}$ August 1997. Published in Dz. U. No 102, item 651 from 2010 with later changes, Republic of Poland

CADASTRAL PORTAL. www.katasterportal.sk/kapor/. January 2014

GOOD GOVERNANCE GUIDE. www.goodgovernance.org.au. February 2014

GUS. Główny Urząd Statystyczny (Central Statistical Office). www.stat.gov.pl. February 2014

Public-Private Partnerships Project Database. Ministry of Economy. bazappp.gov.pl. February 2014

Statistical OfFice OF THE SlovaK RePUbLIC. www.statistics.sk. January 2014 